\title{
In pursuit of "the welfare trait": recycling deprivation and reproducing depravation in historical context
}

\author{
Michael Lambert* \\ Lancaster University
}

\begin{abstract}
Adam Perkins' The Welfare Trait outlines the most recent attempt to provide substance to the existence of an underclass, based on the idea of a shared 'welfare-induced', 'employment-resistant' personality amongst benefit claimants. Following in the footsteps of historian John Macnicol who went 'in pursuit' of the underclass, this article travels 'in pursuit' of the welfare trait by situating its claims in historical context through a comparison of the post-war study by William Tonge, Families without Hope, which sought to identify a common psychological maladjustment in 'problem families.' The common intention, methods and recommendations of the two studies underline their shared purpose: to transfer the social and policy problems associated with poverty from their socio-economic context and the culpabilities of the state to finding the problem in individual families, identifying their behaviour as problematic and proscribing solutions rooted around cultivating personal responsibility.
\end{abstract}

Key words: welfare trait, troubled families, problem families, Sheffield, social work.

\section{Introduction}

In the introduction of his controversial book The Welfare Trait, Adam Perkins anticipated future criticism by arguing that: "this book, despite its scientific and sober tone, risks being mischaracterised as an attempt to undermine the welfare state and/or demonise its claimants' (Perkins, 2016a: 16). Critics have argued that this is exactly what Perkins has done. His book argues for the existence of a 'welfareinduced', 'employment-resistant' type of personality, transmitted across generations of problem families. Those possessing the 'welfare trait,' according to Perkins, tend to have disproportionately large numbers of children and, if left unchallenged, could lead to a 'nightmare scenario' causing national decline. These critics have identified a number of methodological problems relating to his dependency on others' research and use of statistics (Foster, 2016; Nehring, 2016), omission of social and economic issues (Stacey, 2016), lack of consideration for the real experiences of families (Chu, 2016), and his questionable policy recommendations (Jones, 2016). Ultimately, Perkins' argument and those of his critics form part of a long-standing debate surrounding the study of poverty between behavioural and structural causes, and the respective roles and responsibilities of the individual and society (Borrell-Porta, 2016). 
Perkins' contention that there exists a class of people with a 'welfare trait' is the latest in a series of efforts to popularise the notion of an underclass. Following the publication of Charles Murray's Losing Ground (Murray, 1984), historian John Macnicol went 'in pursuit', tracing common features in the behavioural interpretation of poverty which have resurfaced. Here he found six common elements: the administrative nature of its definition, relating to contact with the state; the conflation of intergenerational experiences with inheritance; the identification of some traits as antisocial and their attribution to a single cause; an overriding concern with resource allocation; a desire to restrict the redistributive power of the state; and an enduring call for further research (Macnicol, 1987: 315-6). Such continuities do not begin with Murray in the 1980s. John Welshman has traced the recurrent reinventions of the underclass, from the 'residuum' of the 1880s to current anxiety over 'troubled families' (Welshman, 2013). Yet supporters of Perkins have been keen to highlight its 'novel insights', willingness to tell the 'truth', and a desire to 'open debate' on the subject (Perkins, 2016b; Sabisky, 2016; Young, 2016). However, the idea that there exists a 'welfare trait' found among all benefit claimants is at root recycling the idea that the cause of deprivation is located in the individual, that they are exploiting society, and are anti-social or depraved. Such binary views of behaviour versus structure obscure a complex social problem (Deacon, 1996).

This article examines the claims of Perkins in historical context by reconstructing the research undertaken by psychiatrist William Tonge and others in Sheffield during the 1960s and 1970s concerning maladjustment in 'problem families.' Perkins relies heavily on the final study, published in 1975 . He considered it 'the most rigorous study of the psychological characteristics of problem families' and 'useful for providing background evidence that social and occupational maladjustment is rooted in personality.' (Perkins, 2016a: 24, 114). Yet Tonge's study is fraught with problems of method and approach found in equal measure in Perkins. By examining how Tonge and his collaborators approached their study of 'problem families' in post-war Sheffield, it will throw light on similar limitations in the assumptions of Perkins.

The article develops this contention in three ways. Firstly, by considering who or what 'problem families' were in post-war Britain and how competing definitions emerged. Secondly, on how the term 'problem family' was understood and actually applied to working-class families in the city of Sheffield. Thirdly, how Tonge was reliant on existing definitions of the 'problem family' and the city's social and welfare services with their administrative and professional notions in selecting and defining families for his research. Despite marked discontinuities from post-war social democracy to contemporary neo-liberal state services, notions of family and intervention, continuities endure (Welshman, 2013). By demonstrating the remarkable similarity and continuity between Tonge and Perkins, the shortcomings of narrating what are essentialising and patronising descriptions of difference as a 'scientific and sober tone' become evident.

\section{Problem Families in Post-war Britain}

The idea that there were 'problem families' possessing substandard mores and pathological behaviour emerged in the fallout from evacuation during World War Two. The Women's Group on Public Welfare (WGPW) in their 1943 report Our Towns identified 'problem families' as 'always on the edge of pauperism and crime, riddled with mental and physical defects, in and out of the Courts for child neglect, a menace to the community, of which the gravity is out of all proportion to their numbers' (WGPW, 1943: xiii). 
This 'discovery' was not new. The 'problem family' was rooted in interwar anxieties over the existence of a 'social problem group,' articulated by members of the Eugenics Society (Macnicol, 1986: 26-7; Welshman, 1999: 782-6). The Society were the first to research the 'problem family' in post-war Britain, supported by local authority public health officials, notably Medical Officers of Health (MOH) (Blacker, 1952). The Society were not the only organisation staking a claim to expertise on the 'problem family.' During the late 1940 s and early 1950 s a number of social work, health, welfare and voluntary organisations staked their claim to knowledge on the cause of, and solution to, the 'problem family' which was rooted in their professional skillset (Welshman, 1996). The competing definitions sought to establish a claim to expertise in the postwar welfare state, whose unprecedented material provision nominally 'exposed' the 'problem family' as those unable to make use of the new services available (Philp and Timms, 1957). It also reflected a heightened concern for child welfare and keeping the family at home, rather than removal to an institution (Levene, 2006). However, these definitions were mainly descriptions and always relied on examples rather than evidence and hinged on vivid depictions of 'household squalor' to showcase their inadequacy (Welshman, 2013: 79-81). Despite trouble in defining what a 'problem family' was, this did not prevent local officials identifying and intervening in families whom they deemed a 'problem.' Thus, according to a contemporary, 'problem families' were 'easy to recognise but hard to describe' (Irvine, 1954: 24).

'Problem families' existed and were subjected to arrangements despite the lack of a clear definition. According to Barbara Wootton, a contemporary sceptic, the only common features found in the families were poverty, and those 'whose consumption of social workers' time greatly exceeds the average of the local community' (Wootton, 1959: 55-6). Local practice hinged on identifying such families, and intervening to 'rehabilitate' them to 'normal family life.' Committees, usually under the auspices of the $\mathrm{MOH}$, were established to register families in order to quantify the problem and ensure efficient use of local social services (Taylor and Rogaly, 2007: 430-2). Once identified, families were visited by local workers who used a combination of support and sanction to induce the family, but specifically the mother, towards 'rehabilitation' (Starkey 2000a; 2001: 257-63). Key to this strategy was the work of the Family Service Units (FSUs), which emerged in the same wartime anxieties over "problem families' as evacuation. They provided intensive practical supervision of such families until they could operate at the standards desired of the community; or more accurately the local authority which typically financed the Unit (Starkey, 2000b: 8-76).

What was common to methods of intervention with 'problem families' was an onus on the social services to restore families to normality. In essence, to display poverty in a time of affluence was not a reflection of society, but of the individual, the family, and particularly the mother (Macnicol, 1999: 88-91). Such methods were incredibly pervasive, but not universal. Some local officials and workers dissented from the prevailing view that the continued existence of poverty was the problem of irresponsible families (Todd, 2014). The success or failure of areas to identify and pursue 'problem families' was often at the behest of ardent chief officers and showed considerable local variation in the absence of a national policy. The role of local politics cannot be overlooked in shaping decisions and funding (Davies, 1968) but chief officers were given a certain degree of discretion to manage their services (Gorsky, 2007). Particular 'problem families' were of minor importance compared to other functions, but obtained disproportionate significance under certain chief officers.

Although there was no national policy which dealt with 'problem families', there was a national strategy disseminated from Whitehall, informed by the lobbying of competing health, welfare and social work professional bodies. Following the publication of a further report by WGPW in 1948 showing the merits of local 'problem family' 
committees and intensive family intervention undertaken by FSUs, the government issued a joint circular in 1950 recommending that local authorities establish such practices under the head of a single chief officer (WGPW, 1948). ${ }^{1}$

More circulars followed which reflected the shifting influence of professionals in Whitehall. In 1954 the Ministry of Health issued one recommending Health Visitors under the supervision of MOsH were the best placed to detect and intervene in 'problem families.'2 In 1956 a joint circular reminded local authorities to make use of voluntary organisations concerned with family and child welfare. ${ }^{3}$ In 1959 , following an earlier 1955 report on Unsatisfactory Tenants, the Ministry of Housing and Local Government advocated the use of substandard housing and intensive supervision for 'problem families' by welfare authorities (CHAC, 1955). ${ }^{4}$ Despite the transient emphasis on handling 'problem families' shifting between local authority departments and different health, welfare and social work professions, the unsatisfactory operation of these arrangements was evident in the 1959 Younghusband Report (1959: paras 1068-1104). The passing of the 1963 Children and Young Persons Act effectively, but not definitively, ended the confusion by empowering children's departments to undertake work with 'problem families' on behalf of local authorities. Despite the 'rediscovery' of poverty in the mid-1960s which strengthened structural understanding of poverty (Lowe, 1995), local social services were operating from a model which located entrenched poverty in the failure of the family to perform.

\section{Problem Families and Social Services in Sheffield}

Post-war Sheffield was well furnished with local authority chief officers wedded to the idea and practice of working with 'problem families' as well as a flourishing voluntary sector. At its hearts was the city's MOH Llewellyn Roberts and his Assistant who was also head of the Maternity and Child Welfare Services and chair of the coordinating committee suggested by the 1950 joint circular, Catherine Wright. Wright wrote extensively about 'problem families', addressing local colleagues (Wright, 1960), professional peers (Wright, 1966a), health and medical experts (Wright, 1953; 1955), popular audiences (Wright, 1966b), and was involved in efforts supported by the Eugenics Society to study and research 'problem families' (Wright, 1958; Sheffield City Council, 1961: 47-50; Sheffield Telegraph, 1955).5 In 1955, Wright lost her role as chair of Sheffield's coordinating committee to Bill Freeman, the newly appointed Children's Officer. Like Wright, he had a personal interest in the subject, expanding both preventive and rehabilitation services with 'problem families' run by the authority (Holman, 1998: 36-42; Burnham, 2012: 113; Sheffield City Council, 1959: 11). Her displacement was not acrimonious and Wright instead formed the Problem Family Unit of the Public Health Department.

Buttressing the statutory services were local voluntary organisations, particularly the local FSU and the Sheffield Council of Social Service (SCSS). The FSU was established in 1949 under the direction of Unit leader Donald Rodger and his wife Betty, working closely with the coordinating committee which referred families. Sheffield FSU sought to act as a 'bridge' for families to cross to obtain full status in the welfare state (Rodger, 1962: 6-7; see also Sheffield Family Service Unit, 1959, 4-6; Sheffield Family Service Unit, 1989). Coupled to the intensive casework of the FSU, the SCSS also employed caseworkers to intensively supervise 'problem families.' During the early 1950s they tried to open a residential centre to provide domestic rehabilitation for the mothers of 'problem families,' similar to that established at Brentwood, near Stockport, which had also emerged to deal with the 'problem family' 
during evacuation (Welshman, 2008; Sheffield Council of Social Service, 1947: 5-9; Sheffield Star, 1950).

During the post-war period, Sheffield possessed a number of chief officers acutely interested in the problem of the 'problem family.' They used the full spectrum of permissive powers enabled by central government, and cooperated with a wide range of voluntary agencies pioneering new methods of intervention and rehabilitation. Crucially, and compared to similar ventures in other local authorities, the competing personalities and professions in Sheffield surpassed disciplinary differences and cooperated, pursuing an active agenda with 'problem families' (Rose, 1957a; 1957b; 1957c). Sheffield was a Labour-dominated authority from 1926 until 1968 when the Tories briefly regained power. Under Labour, the city implemented a string of progressive municipal measures including health, housing and unemployment relief (see Levene et al., 2011: 94). However, the post-war period removed much of the autonomy of local councils and strengthened the professional expert. The city's statutory and voluntary welfare services, directed by interested chief officers as part of their expanding welfare functions, coalesced around directing specialised services which identified and intervened in 'problem families' (Hampton, 1993: 138-9; Golding, 1968)). One of the most visible examples of this was the spatial concentration of 'problem families' by the city's coordinating committee, exposed by the city's slum clearance (Hampton, 1970: 24-48, 122-52).

Council housing was in high demand amidst the post-war housing shortage and local officials differentiated the 'unsatisfactory tenants' as those unwilling or unable to pay rent or maintain the property to a suitable standard (Rogaly and Taylor, 2009: 3950). Where threats of eviction did not result in domestic standards being improved or rent being paid, families typically found themselves being referred to the city's coordination committee for action. The process of identifying and moving 'problem families' was increased by the demolition of much of the city's old private rental stock through slum clearance, along with the arrival of families at the city's welfare department in need of temporary accommodation (Adamson et al., 1974: 8-17). Rather than be seen to support queue-jumping, the local authority pursued a strategy of relocating 'problem families' to older and substandard council housing built before 1914 (on its origins see Hebblethwaite, 1987) or moving them into properties earmarked for clearance but not yet demolished. 6 This led to a process where 'problem families' were removed from the decaying industrial core of the city, from areas such as Attercliffe, Grimesthorpe, Darnall and Netherthorpe to older council properties such as the Flower and Brush estates and the lower Manor and Arbourthorne. ${ }^{7}$

By the late 1950s, these estates were already attracting a negative reputation as being 'rough.' This belies the very specific corners of the estates used to concentrate 'problem families' which were often large houses, those with lower rents, or on the physical periphery of the estate (Hodges and Smith, 1954; Frankenberg, 1966: 222-4; Xanthos, 1981: 486-521; Sheffield Telegraph, 1963). This can be further seen by the secondment of FSU workers to the Manor Clinic to be nearer to the large number of 'problem families' being removed to the estates. ${ }^{8}$ In short, the direct effects of Sheffield coordinating committee's policy on rehousing 'problem families' was to create concentrated pockets in substandard properties on the older council estates. This did not mean that the estates were a 'problem', and community and social participation flourished (for the Manor see Fletcher, 2007). 'Problem families' did not constitute the whole estate in the eyes of the authorities, but occupied only a portion of it which they were keep to contain. Moreover, housing comprised only one portion of the definition, which embraced a more generalised concern by health, children's and welfare services, probation officers, social security officials, education welfare officers, and others (see 
Macnicol, 1999: 85-8). Crucially, a 'problem family' was labelled only once it was known to several agencies, and referral across services increased contact and the extent of the 'problem.' However, what is important is that once a family was labelled as a 'problem', the coordinating committee saw fit to remove them to areas occupied by other 'similar' families.

The only real commonality for the families labelled and treated as 'problem families' by the authorities in Sheffield was their subjection and judgment by the different social, health and welfare services of the city. In 1952 Ellinor Black was appointed the head of the University of Sheffield's Social Science Department and established links with the local chief officers to research into the causation of 'problem families' and provide social work training (Burn, 1952: 335; Halsey, 2004: 94; Sheffield Family Service Unit, 1958: 7-8). The appointment of Eric Sainsbury in the Department and his research into the success of intensive casework with 'problem families' exposed the difficulties of finding commonality except contact with the social services (Sainsbury, 1975). The work of the Sheffield Study on Urban Social Structure and Crime posed the same problem. They studied the rates of offending on 'difficult estates' and the lives of repeat offenders but found the issue to be one largely of how the police targeted certain areas and individuals (Baldwin et al., 1976; Mawby, 1979).

The more nuanced and complex methods developed at the University were not repeated in the studies undertaken by Wright and her colleagues in the local authority. After selecting 'problem families' to research from the city's register, they found that parents possessed 'defects or character or mental deficiency' (Wright, 1955: 381), or that family failure was caused by 'parental immaturity and instability' (Parry, Wright and Lunn, 1967: 130) and that these 'characteristics' were being transmitted to their children (Wright and Lunn, 1971: 319-20). Effectively, Wright and her colleagues were using the subjective and elastic criteria used by the coordinating committee to identify 'problem families,' as the means to establish a basis for their sociological definition.

\section{William Lawton Tonge and Families without Hope}

Although fascinated by 'problem families' for years, William Lawton stood largely outside developments in Sheffield prior to his study. As a psychiatrist trained in Manchester, Lawton studied the problem of maladjustment as the cause of unemployment in men (Markowe et al., 1955a, 1955b; Hall and Tonge, 1963) and the incidence of neuroses among women (Tonge et al., 1961). ${ }^{9}$ Here Tonge was part of a wider trend which interpreted improper adjustment to modern society as something within the individual and reflected in 'symptoms' evident to the expert. Such symptoms included unemployment, domestic disputes and other anti-social markers (Porter, 2002; Pickersgill, 2014: 148-51). This was influential in relation to defining residual deviant minorities which remained, despite the provision of the welfare state, of which 'problem families' were the most apparent (Jones, 1979: 83-6). Contemporary studies revealed the 'temperamental instability' (Blacker, 1952: 16) which the various outward signs of failure demonstrated, or the 'emotional immaturity' they expressed (Irvine, 1960: 225).

The lack of any real difference of the 'problem,' from the eugenic position of Blacker to the psychiatric social work one of Irvine, reinforced the process of diagnosis and treatment on behaviour by competing branches of expertise (Swanson, 2006). Tonge's opening remarks on the Families without Hope study published in 1975 contended that all approaches to studying the 'problem family' contained 'the implicit assumption that defective social adjustment was a consequence of defective personality development' (Tonge et al., 1975: 3). Tonge situated Families without Hope within the 
field of psychiatry but also in relation to the purported inadequacies of existing studies of the 'problem family' which he saw as lacking rigour. Many of these local studies by MOsH had been subjected to contemporary methodological criticism (Philp and Timms, 1957: 21-9). Accordingly, the "primary aim of the Sheffield project was to study the nature and extent of the psychiatric pathology in problem families and to distinguish its effects from those of socioeconomic pressures on the social adjustment of these families' (Tonge et al., 1975: 8).

To provide legitimacy, Tonge claimed that the study was 'controlled', but it repeated the same purposes, processes and procedures of previous studies undertaken on 'problem families.' In order to recruit 'problem families' for the study, in 1964 Tonge approached Freeman as the chair of the coordinating committee, for which he received his 'unqualified support' in pursuit of the project. He was less fortunate in finding financial support from the Nuffield Foundation which rejected his proposal, leaving him to secure support from the Endowment Fund of the United Sheffield Hospitals. ${ }^{10}$ Tonge also enlisted the FSU and the Public Health Department's Problem Family Unit (Tonge et al., 1975: xi; Sheffield City Council, 1957: 69-75).

Based on selected test cases from known 'problem families' using the city's register, Tonge did an exploratory survey in 'north' Sheffield (the Flower estate) with the main survey in 'south-east' of the centre (the Manor estate) to find participant families (Tonge et al, 1975: 13). He was, however, wary of studying families based solely on their contact with agencies, as previous $\mathrm{MOH}$ and Eugenic Surveys had done. He was fearful that 'official classification' might reflect the personal judgment of officials, and that 'the selection of problem families had to rely on a more sophisticated procedure than noting the presence of an unkempt garden' (Tonge et al., 1975: 11). He did not want to self-select 'problem families' for study, as Sainsbury had done in his analysis of families who were clients of FSU. Not wanting to restrict a definition in the initial phase, Tonge defined a 'problem family' as one 'which was currently involved with several social agencies', requiring at least three contacts out of the list of fourteen statutory and voluntary health, welfare and children's agencies to qualify. What Tonge's method of selection did, was to duplicate that of the coordinating committee, which referred families based on how much of a 'problem' they were to several agencies.

Having established a class of identifiable 'problem families' to approach for research, Tonge's next obstacle was that of securing their participation, along with finding a 'control' match for the families to contrast their psychiatric adjustment. Fortunately, reliance on Health Visitors and workers from the Problem Family Unit allowed Tonge and his colleagues to make contact and establish a rapport before psychiatric assessments were undertaken (Tonge et al., 1975: 14). In an earlier draft, Tonge noted that of the 40 'problem families' approached, none refused to cooperate, with seven being disqualified by him and his colleagues as either being fatherless or immigrants and unsuitable, whilst 13 of the 'control' families refused outright (Hillam et al., 1970a: 2-5). The fact that 'control' families so readily cooperated with the authorities made their value as 'control' suspect in the eyes of Tonge, who considered many of them 'potential' 'problem families.' Distinguishing the full 'problem family' from the 'potential' was not difficult, as they were 'easily recognised as akin to other groups of problem families which have been described' (Hillam et al., 1970a: 13). Here, Tonge and his colleagues used known understandings of what a 'problem family' was in order to ensure that those eligible for psychiatric assessment were enough of a 'problem.'

Further doubts about differences emerged in the study. Statements from families which did not fit with the researchers' image of them were disregarded when 'considerable doubt' was expressed by the researcher Susan Hillam on their veracity 
(Hillam et al., 1970b: 2-3). When indications of neighbourhood isolation showed little contrast between 'problem' and 'control' families, the terms of socialisation were moved to make such a difference more marked. Social activities of the father were disregarded and instead the housewife became the focus of the study, and informal patterns of association which were difficult to register were disregarded (Hillam et al., 1970c: 3-4). When psychiatric tests were applied, the lack of difference in the children of 'problem' and 'control' families was explained away by the difficult conditions of testing, and was seen to affirm the lower intelligence of 'problem family' parents (Tonge et al., 1975: 39-40). Concluding, Tonge was unable to furnish a definition or typology of the 'problem family', seeing it as 'an arbitrary line' which designated difference, instead finding a 'mosaic of social maladjustment' (Tonge et al., 1975: 1146). However, he saw the 'collapse of morale' of the mother as the key separation point between the 'problem' and the 'control' family. This, he argued, was based on personal inadequacy developed in childhood, often linked to emotional immaturity in mothers, frustration in fathers and effectively 'living without hope' (Tonge et al., 1975: 117-21). As with other researchers, Tonge found that 'problem families' existed, despite misgivings.

The normative assumptions permeating the approach and process of Tonge's research are evident. The method comprises of selecting 'problem families' from areas where local authority services are concentrating them, differentiating them from the 'control' - working class - population, and then subjecting them to psychoanalytical assessment which confirms their purported behavioural anomalies as maladjustment. That he selected families through the same mechanisms as the local authorities by the arbitrary criteria of contact with social agencies serves to repeat the same types of 'problems' found among families and used in the processes of stating their differences. As Wootton argued in 1959: 'none of these labels - low intelligence, emotional immaturity or psychopathic personality - can have any meaning except in terms of criteria which are themselves independent of the behaviour which they are invoked to explain' (Wootton, 1959: 62 emphasis added).

Tonge's study had an epitaph following his death in 1976. Sir Keith Joseph's discovery of a 'cycle of deprivation' renewed interest in the 'problem family' and generated a series of research studies which were less emphatic on the idea of intergenerational inheritance than Tonge's colleagues (Tonge et al., 1983; Welshman, 2012). The importance of continuing to identify 'problem families' despite being unable to find a typology has repercussions when it comes to suggestions for policy solutions. Tonge argued that 'it is of the greatest importance to identify families at risk at a very early stage and to persuade them of their pressing need for limitation of family size', preferably through 'voluntary' sterilisation or contraceptive devices which required no room for error on the part of the 'problem' mother (Tonge et al., 1975: 122).

At the same time, Wright and her successor Marion Jepson were spearheading Sheffield's domiciliary family planning service which identified women 'at risk' and provided contraceptive services direct to the door (Sheffield City Council, 1971: 21-8, 53). ${ }^{18}$ Such a scheme, pioneered in the early 1960 s specifically to deal with the fertility of 'problem families' was given national sanction by Joseph under measures to alleviate the 'cycle of deprivation' (Allen, 1974: 1-2, 1976: 1-8).11 Although the intended targeted measure to reduce the fertility of 'problem families' did not materialise as Joseph, Wright or others intended, it points to the common solution after a behaviourally incapable residual class of families have been identified: limit their fertility. Similar suggestions were also touted in earlier Eugenic Society "problem family' studies (Wofinden, 1950) which had also advocated such suggestions in the inter-war period, before they became unpopular and unfashionable (Macnicol, 1989). 


\section{Conclusion}

Perkins' recommendations at the end of The Welfare Trait then, mirror those of Tonge. $\mathrm{He}$ sees the macro-level solution in reducing benefits which encourage the 'employment-resistant' to reproduce, rather than developing micro-level policies as undertaken with 'problem families.' That Perkins and Tonge reached the same solution highlights their shared point of departure in efforts to homogenise the disparate experiences of families into a common type. In both instances, this has been based on individualising administratively defined characteristics, rather than seeing how they have been shaped by the capacities of the state, as they undoubtedly were in Sheffield in the 1960s. For Perkins this is compounded by his use of data gathered for the Troubled Families Programme to buttress his hypothesis, which much like the "problem families' policies of the post-war period, reproduces administrative anxieties and knowledge of their contacts, rather than any degree of commonality amongst families identified (Crossley, 2015).

When John Macnicol went 'in pursuit' of the underclass, what he discovered was the role that researchers, experts and the state play in producing and reinforcing concerns about the poor and their behaviour to the neglect of the socio-economic structures and forces which shape their understanding of, and approaches to the problem of poverty. Similarly, trailing 'in pursuit' of the 'welfare trait' through an examination of how Tonge and his colleagues sought to uncover the maladjusted personality problems of 'problem families' in 1960s Sheffield, exposes what at root are efforts essentialising characterisations of difference under a veneer of scientific legitimacy. 'Problem families' did exist, but only in the imagination and administration of researchers, welfare and health officials who sought to explain and understand the continued experience of poverty amidst prosperity in post-war Britain. Perkins' view that the studies of others, particularly Tonge, act as a 'sanity check' (Perkins, 2016a: 185 ) on the validity of his findings should be given credence. Not, as Perkins would argue, by his aims in his research and findings, but by a historical understanding of the how 'problem families' in post-war Sheffield were defined and identified by the state.

\section{Acknowledgements}

This research forms part of a doctoral project on "'Problem families" in post-war England' undertaken at Lancaster University and funded by the Economic and Social Research Council [ES/J5000094/1]. Thanks are extended to the librarians, staff and archivists at Sheffield Archive, Sheffield Local Studies Library, Warwick Modern Records Centre, Liverpool University Special Collections and Archives, Liverpool Record Office, Lancashire Archives, Community Futures, Manchester University Special Collections, the Wellcome Library and the National Archives for viewing material. Particular thanks are due to David Holmes of Family Action for granting permission to consult material relating to Family Service Units, for Robin Wiltshire at Sheffield Archives for arranging access to closed documents relating to 'problem families' in Sheffield, and Helena Smart of Liverpool Record Office for arranging permission to view similar material on 'problem families' held in Liverpool. I would also like to thank Emily Ball and the two anonymous reviewers for their comments and suggestions. 
p. 234. In pursuit of "the welfare trait": recycling deprivation and reproducing depravation in historical context

\section{Notes}

1 T[he] N[ational] A[rchives], London HLG 101/297 Home Office, Ministry of Health and Ministry of Education, 'Children neglected or ill-treated in their own homes', Joint Circular 157/50, 78/50 and 225/50, 31 July 1950.

2 TNA MH 134/181 Ministry of Health, 'Health of children: prevention of break-up of families', Circular 27/54, 30 November 1954.

3 TNA, ED 147/1019 Home Office, Ministry of Health and Ministry of Education, 'Coordination of the statutory and voluntary services', Joint Circular 118/56, 16/56 and 311/56, 22 August 1956.

4 TNA, HLG 101/297, Ministry of Housing and Local Government and Ministry of Health, 'Homeless families', Joint Circular 17/59 and 4/59, 18 March 1959.

5 S[heffield] A[rchives], Sheffield, CA520/19 Notes of a talk given by Catherine Wright to Sheffield Coordinating Committee, 6 September 1966.

6 L[iverpool] R[ecord] O[ffice], Liverpool, 352 MIN/JOIN/15/1 Report on accommodation for problem families in ten local authorities by Liverpool Town Clerk, 25 October 1963.

7 This tendency of origin and relocation of families can be seen in the addresses of the 42 surviving case records of families referred to the Brentwood Recuperative Centre from Sheffield 1947-55, and the addresses of families dealt with by the coordinating committee. L[ancashire] A[rchives], Preston, DDX2302/boxes 4-23 Admissions, 1943 70; C[ommunity] F[utures], Preston, Box 57 Admissions, 1943-55; SA, CA520/19 Children's Case Committee minutes and records, 1952-69.

8 SA, CA520/19 Some thoughts on FSU by Donald Roger, 7 June 1966.

$9 \mathrm{M}$ [anchester] U[niversity] S[pecial] C[ollections], Manchester, GB $133 \mathrm{MC} / 2 /$ Tonge MD entry, 1960.

10 SA, CA694/7 William L Tonge to Bill Freeman, 9 March 1964 and reply from Bill Freeman, 13 March 1964.

11 TNA MH 156/245 B R Rayner to Mr Hart, 6 June 1972.

*Correspondence address: Michael Lambert, Department of History, Lancaster University. Email: m.lambert@lancaster.ac.uk.

\section{References}

Adamson, C., Brierley, J., Crook, T., Price, R. and Soyd, R. (1974) Homeless families in Sheffield. Sheffield: Sheffield Shelter Group.

Allen, I. (1974) Birth control in Runcorn and Coalville. London: PEP.

Allen, I. (1976) Family planning services in the home. London: PEP.

Baldwin, J., Bottoms, A.E. and Walker, M.A. (1976) The urban criminal: a study in Sheffield. London: Tavistock.

Blacker, C. P. (ed.) (1952) Problem families: five enquiries. London: Eugenics Society.

Borrell-Porta, M. (2016) Worklessness is not a trait: why blaming and shaming is not a solution. LSE Politics and Policy (12 April 2016). Available from: http://blogs.Ise.ac.uk/politicsandpolicy/worklessness-is-not-a-trait-why-blamingand-shaming-is-not-a-solution/ [Accessed: 19 May 2016]. 
p. 235. In pursuit of "the welfare trait": recycling deprivation and reproducing depravation in historical context

Burn, J.L. (1952) The problem of the child neglected or ill-treated in his own home. Journal of the Royal Sanitary Institute, 72, 4, 326-36.

Burnham, D. (2012) The social worker speaks: a history of social workers through the twentieth century. Farnham: Ashgate.

Central Housing Advisory Committee (CHAC) (1955) Unsatisfactory tenants. London: HMSO.

Chu, B. (2016) It's absurd to tie being "workless" to doing no work. Just ask a mother. Independent (10 March 2016). Available from: http://www.independent.co.uk/voices/family-is-something-economists-struggleto-measure [Accessed: 19 May 2016].

Crossley, S. (2015) "Realising the (troubled) family", "crafting the neoliberal state." Families, Relationships and Societies, advanced online access.

Davies, B. (1968) Social needs and resources in local services. London: Michael Joseph.

Deacon, A. (1996) The dilemmas of welfare: Titmuss, Murray and Mead, In: Green, S.J.D. and Whiting, R.C., (eds) The boundaries of the state in modern Britain. Cambridge: Cambridge University Press, 191-212.

Fletcher, D.R. (2007) A culture of worklessness? Historical insights from the Manor and Park area of Sheffield. Policy and Politics, 35, 1, 65-85.

Foster, D. (2016) Adam Perkins: "Welfare dependency can be bred out." Guardian (9 March 2016). Available from: http://www.theguardian.com/society/2016/mar/09/adam-perkins-welfaredependency-can-be-bred-out [Accessed: 19 May 2016].

Frankenberg, R. (1966) Communities in Britain: social life in town and country. Harmondsworth: Pelican.

Golding, W. M. (1968) "Is happiness a non-event”? Sheffield Forward, 6, 283, 4-5.

Gorsky, M. (2007) Public health past and present: local leadership in public health: the role of the Medical Officer of Health in Britain. Journal of Epidemiology and Community Health, 61, 6, 468-72.

Hall, P. and Tonge, W. L. (1963) Long-standing continuous unemployment in male patients with psychiatric symptoms. British Journal of Preventive and Social Medicine, 17, 4, 191-6.

Halsey, A. H. (2004) A history of sociology in Britain: science, literature and society. Oxford: OUP.

Hampton, W. (1970) Democracy and community: a study of politics in Sheffield. Oxford: OUP.

Hampton, W. (1993) Optimism and growth, 1951-1973, In: Binfield, C., Childs, R., Harper, R., Hey, D., Martin, D. and Tweedale, G. (eds.) The history of the city of Sheffield, 1843-1993: volume l: politics. Sheffield: Sheffield Academic Press, 119-49.

Hebblethwaite, R. (1987) The municipal housing programme in Sheffield before 1914. Architectural History, 30, 143-79.

Hillam, S. M., James, D. S. and Tonge, W. L., (1970a) Problem families - I: specific failure or total failure? Sheffield: Whiteley Wood Clinic, 1970

Hillam, S. M., James, D. S. and Tonge, W. L., (1970b) Problem families - II: poverty, unemployment and debt. Sheffield: Whiteley Wood Clinic, 1970

Hillam, S. M., James, D. S. and Tonge, W. L., (1970c) Problem families - III: kinship, neighbourhood and community. Sheffield: Whiteley Wood Clinic

Hodges, M. W. and Smith, C. S. (1954) The Sheffield estate, in Liverpool University Social Science Department, Neighbourhood and community. Liverpool: Liverpool University Press, 79-133.

Holman, B. (1998) Child care revisited: The Children's Departments, 1948-71. London: London Institute of Child Care and Social Education. 
Irvine, E. E. (1954) Research into problem families: theoretical questions arising from Dr Blacker's investigations. British Journal of Psychiatric Social Work, 9, 24-33.

Irvine, E. E. (1960) Some notes on problem families and immaturity. Case Conference, $6,9,225-8$.

Jones, C. (1979) Social work education, 1900-1977, in Parry, N., Rustin, M. and Satyamurti, C. (eds.) Social work, welfare and the state. London: Edward Arnold, 72-88.

Jones, K. S. (2016) Antisocial personality and lack of conscientiousness is correlated with bogus anti-welfare research. Politics and Insights Blog (11 March 2016). Available from: https://kittysjones.wordpress.com/2016/03/11/antisocialpersonality-and-a-lack-of-conscientiousness-is-correlated-with-bogus-welfareresearch/ [accessed 19 May 2016].

Levene, A. (2006) Family breakdown and the "welfare child" in $19^{\text {th }}$ and $20^{\text {th }}$ century Britain. History of the Family, 11, 2, 67-79.

Levene, A., Powell, M., Stewart, J. and Taylor, B. (2011) Cradle to grave: municipal medicine in interwar England and Wales. Bern: Peter Lang.

Lowe, R. (1995) The rediscovery of poverty and the creation of the Child Poverty Action Group, 1962-1968. Contemporary Record, 9, 3, 602-11.

Macnicol, J. (1986) The effect of the evacuation of schoolchildren on official attitudes to state intervention, in Smith, H. (ed.) War and social change: British society in the Second World War. Manchester: Manchester University Press, 3-31.

Macnicol, J. (1987) In pursuit of the underclass. Journal of Social Policy, 16, 3, 293 318.

Macnicol, J. (1989) Eugenics and the campaign for voluntary sterilization in Britain between the wars. Social History of Medicine, 2, 2, 147-70.

Macnicol, J. (1999) From "problem family" to "underclass", 1945-95, In: Fawcett, H. and Lowe, R. (eds.) Welfare policy in Britain: The road from 1945. Basingstoke: Macmillan, 69-93.

Markowe, M., Tonge, W. L. and Barber, L. E. D. (1955a) Psychiatric disability and employment: I. survey of 222 registered disabled persons. British Journal of Preventive and Social Medicine, 9, 1, 39-45.

Markowe, M., Tonge, W. L. and Barber, L. E. D. (1955b) Psychiatric disability and employment: Il. follow-up of 95 unemployed subjects. British Journal of Preventive and Social Medicine, 9, 1, 46-47.

Mawby, R. I. (1979) Policing the city: a case study of crime and law enforcement in Sheffield. Farnborough: Saxon House.

Murray, C. (1984) Losing ground: American social policy, 1950-1980. New York: Basic Books.

Nehring, D. (2016) Manufactured controversy: Adam Perkins, the psychological imagination and the marketing of scholarship. Social Science Space (18 March 2016). Available from: http://www.socialsciencespace.com/2016/03/manufactured-controversy-adamperkins-the-psychological-imagination-and-the-marketing-of-scholarship/ [Accessed: 19 May 2016].

Parry, W.H., Wright, C.H. and Lunn, J.E. (1967) Sheffield problem families: a follow-up survey. Medical Officer, 118, 130-2.

Perkins, A. (2016a) The welfare trait: how state benefits affect personality. Basingstoke: Palgrave MacMillan.

Perkins, A. (2016b) The ugly truth about benefits. CENSORED by a left wing hate mob. Why? Because top academic wanted to tell students welfare can make claimants workshy, aggressive and anti-social. Daily Mail (21 February 2016). Available from: $\quad$ http://www.dailymail.co.uk/debate/article-3456651/The-ugly-truthbenefits-CENSORED-LSE-students-academic-tried-tell-welfare-make-claimantsworkshy-agressive-anti-social [Accessed: 19 May 2016]. 
Philp, A. F. and Timms, N. (1957) The problem of "The Problem Family". London: FSU.

Pickersgill, M. (2014) The endurance of uncertainty: antisociality and ontological anarchy in British psychiatry, 1950-2010. Science in Context, 27, 1, pp. 143-75.

Porter, D. (2002) From social structure to social behaviour in Britain after the Second World War. Contemporary British History, 16, 3, 58-80.

Rodger, D. (1962) The aims, work and practice of Family Service Units, with special reference to the Sheffield unit. Sheffield: FSU.

Rogaly, B. and Taylor, B. (2009) Moving histories of class and community: identity, place and belonging in contemporary England. Basingstoke: Palgrave Macmillan.

Rose, G. (1957a) Coordinating committees - I. Case Conference, 4, 2, 41-6.

Rose, G. (1957b) Coordinating committees - II. Case Conference, 4, 3, 75-7.

Rose, G. (1957c) Coordinating committees - III. Case Conference, 4, 4, 111-4.

Sabisky, A. (2016) A review of Adam Perkins's "The Welfare Trait." Adam Smith Institute (11 January 2016). Available from: http://www.adamsmith.org/blog/miscellaneous/a-review-of-adam-perkinss-thewelfare-trait [Accessed: 19 May 2016].

Sainsbury, E. (1975) Social work with families: perceptions of social casework among clients of a Family Service Unit. London: Routledge and Kegan Paul.

Sheffield City Council (1957) Annual report of the Medical Officer of Health. Sheffield: City Council.

Sheffield City Council (1959) Annual report of the Children's Officer. Sheffield: City Council).

Sheffield City Council (1961) Annual report of the Medical Officer of Health. Sheffield: City Council.

Sheffield City Council (1971) Annual report of the Medical Officer of Health. Sheffield: City Council.

Sheffield Council of Social Service (1947) Annual report. Sheffield: SCSS.

Sheffield Family Service Unit (1958) Annual report. Sheffield: FSU.

Sheffield Family Service Unit (1959) Annual report. Sheffield: FSU.

Sheffield Family Service Unit (1989) How it all began: Sheffield Family Service Unit, 1949-1989. Sheffield: FSU.

Sheffield Star (1950) Centre idea for problem families. Sheffield Star, 1 December.

Sheffield Telegraph (1955) Problem families: city doctor urges new outlook. Sheffield Telegraph, 27 September.

Sheffield Telegraph (1963) This isn't life on a city estate - councillor. Sheffield Telegraph, 29 May.

Stacey, T. (2016) The hateful trait: demonisation of poor reaches new low. Equality Trust (3 March 2016). Available from: https://www.equalitytrust.org.uk/hatefultrait-demonisation-poor-reaches-new-low [Accessed: 19 May 2016].

Starkey, P. (1998) The Medical Officer of Health, the social worker, and the Problem Family, 1943-1968: the case of Family Service Units. Social History of Medicine, 11, 3, 421-441.

Starkey, P. (2000a) The feckless mother: women, poverty and social workers in wartime and post-war England. Women's History Review, 9, 3, 539-557.

Starkey, P. (2000b) Families and social workers: The Family Service Units, 1940-1985. Liverpool: Liverpool University Press.

Starkey, P. (2001) Mental incapacity, ill health and poverty: family failure in post-war Britain, in Lawrence, J. and Starkey, P. (eds.) Child welfare and social action in the nineteenth and twentieth centuries. Liverpool: Liverpool University Press, 256-76.

Swanson, G. (2006) Serenity, self-regard and the genetic sequence: social psychiatry and preventive eugenics in Britain, 1930s-1950s, New Formations, 60, 1, 50-65.

Taylor, B. and Rogaly, B. (2007) "Mrs Fairly is a dirty, lazy type": unsatisfactory households and the problem of problem families in Norwich, 1942-1963. Twentieth Century British History, 18, 4, 429-452. 
p. 238. In pursuit of "the welfare trait": recycling deprivation and reproducing depravation in historical context

Todd, S. (2014) Family welfare and social work in post-war England, c. 1948-1970. English Historical Review, 129, 537, 362-87.

Tonge, W. L., Cammock, D. W., Winchester, J. S. and Winchester, E. N. M. (1961) Prevalence or neurosis in women. British Journal of Preventive and Social Medicine, 15, 4, 177-9.

Tonge, W. L., James, D. S. and Hillam, S. M. (1975) Families without hope: a controlled study of 33 problem families. Ashford: Headley.

Tonge, W. L., Lunn, J. E., Greathead, M., McLaren, S. and Bosanko, C. (1983) Generations of "problem families" in Sheffield, in Madge, N. (ed.) Families at risk. London: Heinemann, 37-59.

Welshman, J. (1996) In search of the "problem family": public health and social work in England and Wales 1940-70. Social History of Medicine, 9, 3, 447-465.

Welshman, J. (1999) Evacuation, hygiene and social policy: The "Our Towns" report of 1943. Historical Journal, 42, 3, 781-807.

Welshman, J. (2008) Recuperation, rehabilitation and the residential option: The Brentwood Centre for mothers and children. Twentieth Century British History, 19, 4, 502-29.

Welshman. J. (2012) From transmitted deprivation to social exclusion: policy, poverty and parenting. Bristol: Policy Press.

Welshman, J. (2013) Underclass: a history of the excluded since 1880. London: Bloomsbury.

Wofinden, R. (1950) Problem families in Bristol. London: Eugenics Society.

Women's Group on Public Welfare (WGPW) (1943) Our towns. London: OUP.

Women's Group on Public Welfare (WGPW) (1948) The neglected child and his family. Oxford: OUP.

Wootton, B. (1959) Social science and social pathology. London: George Allen and Unwin.

Wright, C. H. (1953) Care and supervision of problem families. Medical Officer, 90, 239.

Wright, C. H. (1955) Problem families: a review and some observations. Medical Officer, 94, 381-4.

Wright, C. H. (1958) Problem families. Eugenics Review, 50, 1, pp. 35-6.

Wright, C. H. (1960) The problem family father, in Sheffield Public Health Department Education Service, Health Education and Information Bulletin, 7, 49-51.

Wright, C. H. (1966a) A children's club as a preventive service. Case Conference, 12, 9, 312-6.

Wright, C. H. (1966b) Helping the children in problem families. Mother and Child, 38, 4, 7-9.

Wright, C. H. and Lunn, J. E. (1971) Sheffield problem families: a follow-up study of their sons and daughters. Community Medicine, 126, 22, 301-7, 315-21.

Xanthos, P. D. (1981) Crime, the housing market and reputation: a study of some local authority estates in Sheffield. Unpublished PhD thesis: University of Sheffield.

Young, T. (2016) Tell the truth about benefit claimants and the left shuts you down. Spectator (16 January 2016). Available from: http://www.spectator.co.uk/2016/01/tell-the-truth-about-benefit-claimants-andthe-left-shuts-you-down/ [accessed 19 May 2016].

Younghusband, E. (1959) Report of the working party on social workers in the local authority health and welfare services. London: HMSO. 